\title{
Assessment of Municipal Solid Waste Management for Better-Quality Public Health and Environmental Sustainability in the Freetown Metropolitan City in Sierra Leone
}

\author{
Tamba Komba \\ Geology Department, Fourah Bay College, University of Sierra Leone, Freetown, Sierra Leone \\ Email: tamba.komba@usl.edu.sl,tamsuccess2015@gmail.com
}

How to cite this paper: Komba, T. (2021). Assessment of Municipal Solid Waste Management for Better-Quality Public Health and Environmental Sustainability in the Freetown Metropolitan City in Sierra Leone. Journal of Geoscience and Environment Protection, 9, 33-49.

https://doi.org/10.4236/gep.2021.94004

Received: February 5, 2021

Accepted: April 13, 2021

Published: April 16, 2021

Copyright $\odot 2021$ by author(s) and Scientific Research Publishing Inc. This work is licensed under the Creative Commons Attribution International License (CC BY 4.0). http://creativecommons.org/licenses/by/4.0/ Open Access

\begin{abstract}
Managing waste has been an aged-old challenge, especially in developing cities, like the Freetown Metropolitan City. Solid Waste and/or waste in general is an artefact of human activities that can spring from individuals, families, community, commercial/industrial operations etc. This study is a qualitative investigation, and it is intended to gather an inclusive knowledge of solid wastes management for better public health in Freetown, the Capital City of Sierra Leone. Statistical analysis was employed to observe numerical representations on a wide range of selected data. In an attempt to achieve the aim of this research project, reviews of available online resources were exploited, and juxtaposed with everyday knowledge in the existing state of the Freetown's municipality solid waste management. The study revealed that residents in Freetown produce an average $0.45 \mathrm{~kg}$ of solid waste per individual per day. It was further established that biodegradable/organic matters comprise approximately $75 \%$ to $85 \%$ of total waste stream along with assorted retired furniture, scarp metals and plastic bags as most important recyclable elements. The hitches connected with municipal solid waste management in Freetown have become palpable, spanning from the past decade to date. Among many other factors, an upsurge influx urbanisation after the 11 years brutal civil war that ended in 2001, combine up with insufficient approved dumping sites for waste disposal and institutional incapability stand out. In this project, the contemporary approach of solid waste disposal in Freetown was carefully assessed with efforts to bring out the most feasible alternatives of solid waste disposal and acclaim ways of refining its activities. It was concluded from the study that, solid wastes in the Freetown Municipality must be tackled in a synergetic approach. That is, government corroborating with
\end{abstract}


private solid waste managing actors so as to enhance an excellent better-public health, sustainable environmental, urban economic development and a resourceful energy paradigm.

\section{Keywords}

Municipality, Solid Waste Management, Sustainable, Public Health, Environmental Development

\section{Introduction}

The need to control natural resources exhaustion, climate change and protect a healthy living environment for an ever-growing human population has become a global task and challenge. This increases the request to curtail solid waste generation, and the judicious management of solid waste arising from everyday's consumption of material resources on a worldwide perspective. Several countries are now introducing a process of change; that is, from the traditional scheme of waste disposal by means of simple discarding or landfilling, in the direction of the gradual application of a closed loop management of their generated solid wastes through the circular economy paradigm.

Freetown municipality is facing rapid urbanisation per annum for the past decade following the end of the civil war. This has been leading to overcrowding, and unavoidably the development of slumps and informal settlements with poor waste management practices. According to Ferede (2011), urban residents generally consume more resources than rural settlements, and as such, generate large quantity of solid waste.

Waste management in the Freetown City is often influenced, if not hampered by the land tenure system in which many tenants do not have an absolute right to the land they temporarily live on. Consequently, tenants are unable to effectively manage their waste domestically (Unruh, 2008; Government of Sierra Leone, 2015a; Kaindaneh, 2015; Ochiai, 2016; Ahene et al., 2019). The aftermath is that many communities' drainage channels, paved and unpaved gutters and roads are highly littered with waste. This is compounded when people in high-density jam-packed areas do not have authorized access to garbage disposal containers and/or communal waste disposal sites. Moreover, private waste collectors are seemingly expensive for the poor households, pushing them to the extreme of practicing indiscriminate waste disposal within their environment.

Waste is any unwanted material that is connected to human developmental activities. Understandably, some constituents of waste have perceived economical value and can be recycled once acceptably recovered and improved upon. The concept of Waste is sometimes subjective, as substances that some people abandon may have worth to other persons. Waste, if not properly disposed of, can threaten the environment and health of people living around it.

Solid waste has been defined by several authors in many ways, but generally, it 
represents anything that is neither liquid nor gas and is discarded as unwanted by the producer (Mishra, Mishra and Tiwari, 2014). In the same way, a number of literatures such as (Reed and Mena-Moreno, 2016) describe solid waste, as all the wastes arising from human and animal activities that are generally solid and are discarded as unusable or unwanted by the person or organization that produces it. According to Soni, Patil and Argade (2016) and (Acharya, 2018) municipal solid wastes are described as all wastes that result from municipal services such as street sweeping, dead animals, market waste and institutional wastes that are not hazardous. Also, Solid waste management is described as the discipline connected to the control of generation, storage, collection, transfer and transport, processing and disposal of waste in a manner that is in accordance with the best principles of public health, economic, and should be responsive to public attitudes (Tchobanoglous and Kreith, 2002).

Similarly, Municipal Solid waste Management (MSWM) is the collection, transfer, treatment, recycling, resource recovery, and disposal of solid waste generated in urban areas (Bernstein, 2004; Ogwueleka, 2009).

From the perspective of MSWM, solid waste storage, skip point and containers figuratively have comparable functions, but they do portray slightly different connotations. Solid waste storage implies that the garbage and trash are produced by a household and placed in prearranged containers before it is collected for transfer to another step in the waste management cycle. Whereas, skip point is defined as a container possessed by the municipality and made available to Micro and Small Enterprises (MSE) and residents for their use as part of the municipality's solid waste collection system.

The container is also defined as any storage container provided by a waste service provider (hauler) for the purposes of garbage, recycling and organics collection. This container should be consistent throughout the city as much as conceivable, and it is made from galvanized steel and non-combustible materials.

Amongst others, key influential factors that had, and continue to impede effective solid waste management for better-quality public health and environmental sustainability in Freetown have been attributed to a number of issues. These constraining factors are not limited to insufficient governing framework; which has demonstrated in lack of interest by private sectors' investment in solid waste management services, inept institutional involvements, lack and/or low political drive to encourage community participation in waste management, poor data and information capacity for planning, wrong perception and attitude of waste producer etc. (Sood, 2004; Gogra, Yao, Kabba, Sandy, Zaray, Gbaniea et al., 2010). With increase in population, urbanization and industrialization, the challenge of solid waste management in the Freetown Metropolitan has amplified and become more multifaceted now than ever before. There is an increase in demand for a good (qualitative) waste management facility that will enhance public health and environmental sustainability in Freetown City. On this backdrop, an absolute necessity does exist for a qualitative assessment of the existing 
municipal solid waste management practice in Freetown City. Therefore, the main goal of this study was to carry out a qualitative assessment for better-quality public health and environmental sustainability in the Freetown Metropolitan City. Qualitative approach is employed in this study because, a number of literatures and studies had focused on the quantitative aspect of solid waste management practice in the city. Of course, this qualitative study could have been barely possible in itself without incorporating some of those quantitative literatures and studies.

\section{Statement of the Problems}

Municipal Solid waste management has been an enormous challenge, not only to developing nations, but also the developed countries of the world. Freetown, the Capital City of Sierra Leone, and the central hub for trade and economic activities is characterized by a mixed swift growing population primarily due to natural increase and migration from rural areas after the 11 years civil war. Such fast upsurge in population, alongside with rapid infrastructural development in the city has resulted in growing volumes of solid waste and in turn puts pressure on the available infrastructures. However, the Freetown City Council (FCC) and other private sector like "Masada" and "Klin Salone" etc. that are responsible for solid waste management activities in the municipality could not satisfy the above necessities adequately. Most of the solid wastes that are produced in the city invariably keep on uncollected and/or simply dumped in open zones such as; paved and unpaved gullies, road sides, unfinished houses, seasonal streams, brooks and market places especially at night (Figure 1, Figure 2(a) \& Figure $2(b))$. The solid waste disposal technique that is being practiced is also an open dumping system, which is extensively adopted in many developing nations. The resultant of such unscientific and uncultured practice is a hazardous obnoxious effect on health and the environment at large.

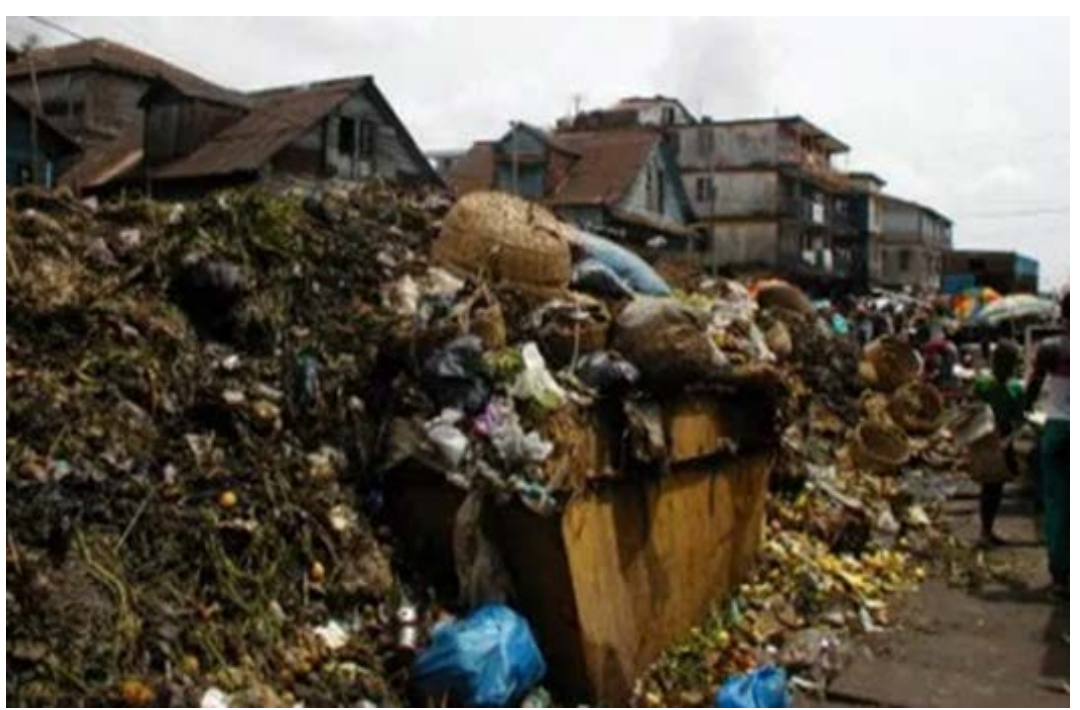

Figure 1. Effect of late collection of skip container (run-off and litters the ground). 

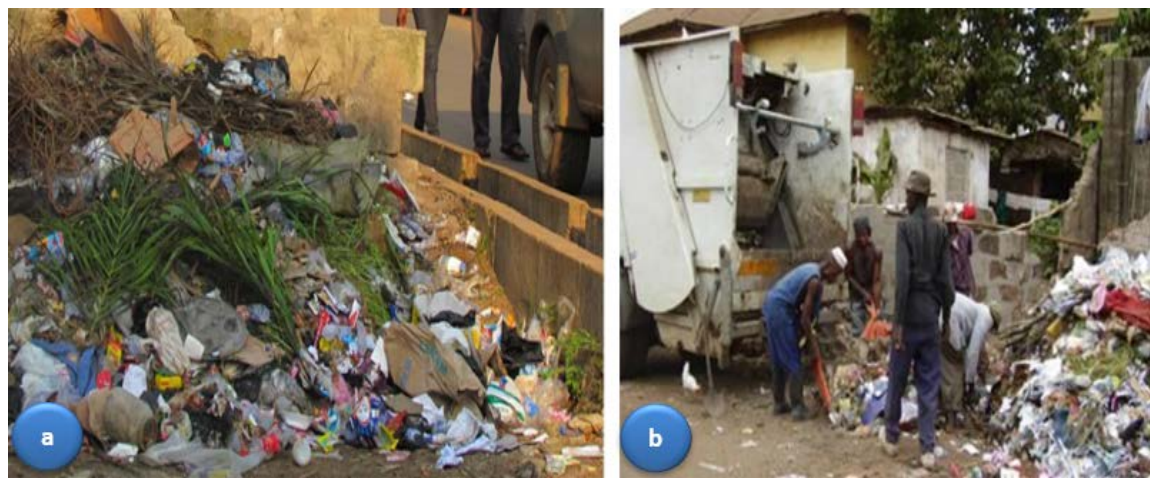

Figure 2. (a \& b) Waste indiscriminately disposed along major streets in Freetown municipality.

Municipal solid waste management in the Freetown metropolitan has not been carried out in a satisfactory and suitable approach. From time to time, this has led to water-borne diseases like Cholera, dysentery, typhoid and also a deterioration of the aesthetic of the city in the form of flooding during heavy precipitation as the wastes get clogged in the drainages (Figure 3).

There is an absolute necessity to improve the efficiency of municipal solid waste management in the Freetown Municipality, as it has an overarching influence on the health condition of its residents, the aesthetic of the city, economic growth and environmental sustainability.

\section{Description of the Study Area}

The study area is in Freetown, the capital city of Sierra Leone, in West Africa (Figure 4). Freetown was founded on $11^{\text {th }}$ March, 1792 , and is located on $8.48^{\circ} \mathrm{N}$ and $13.23^{\circ} \mathrm{W}$ with a total area of 357 square kilometers. It is situated along the Atlantic Coast on a funnel shaped igneous intrusion (Chalokwu, 2001; Callegaro et al., 2017; Redshaw et al., 2019). Freetown lies on $47 \mathrm{~m}$ above sea level, and it has a tropical climate. There is substantial rainfall in most months of the year. The Classification sub-type for this climate is "Am"-Tropical Monsoon Climate (Peel, Finlayson, and McMahon, 2007). The average temperature in Freetown is $26.2^{\circ} \mathrm{C} \mid 79.2^{\circ} \mathrm{F}$. The rainfall here is around $3657 \mathrm{~mm}$ per year. The warmest month, on average, is April with an average temperature of $83.0^{\circ} \mathrm{F}\left(28.3^{\circ} \mathrm{C}\right)$. The coolest month on average is July, with an average temperature of $25.6^{\circ} \mathrm{C} \mid 78.0^{\circ} \mathrm{F}$. The city is the commercial financial and cultural centre of Sierra Leone, where the economy circles mostly about its harbour inhabiting a part of the estuary of the Sierra Leone River. This harbour is one of the world's largest natural harbour, Queen Elizabeth 11 Quay.

The problems of solid waste management in Freetown Municipality can be drawn far back as in the late 60s (Gogra, Yao, Kabba, Sandy, Zaray, Gbaniea et al., 2010) when the management has been under varying organizations-both private and public.

Freetown City is divided into three major municipal regions; the East End, Central, and the West End. These three regions are sub-divided into 8 electoral 


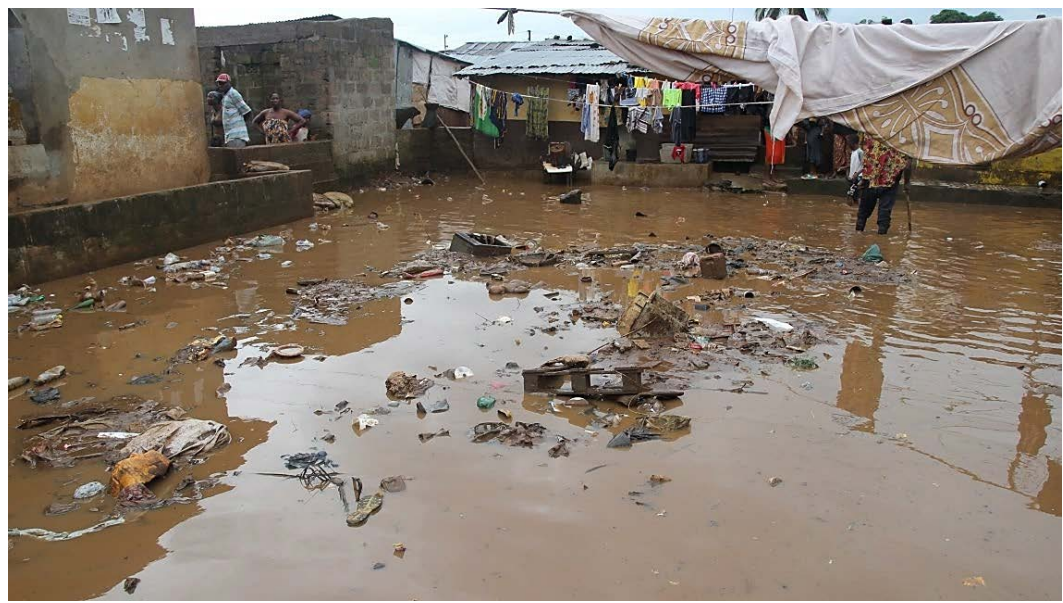

Figure 3. Flooded homes in Freetown, Sierra Leone following the mudslide and flooding that hit on 14 August 2017. Photo: Kristin Myers/Concern Worldwide.

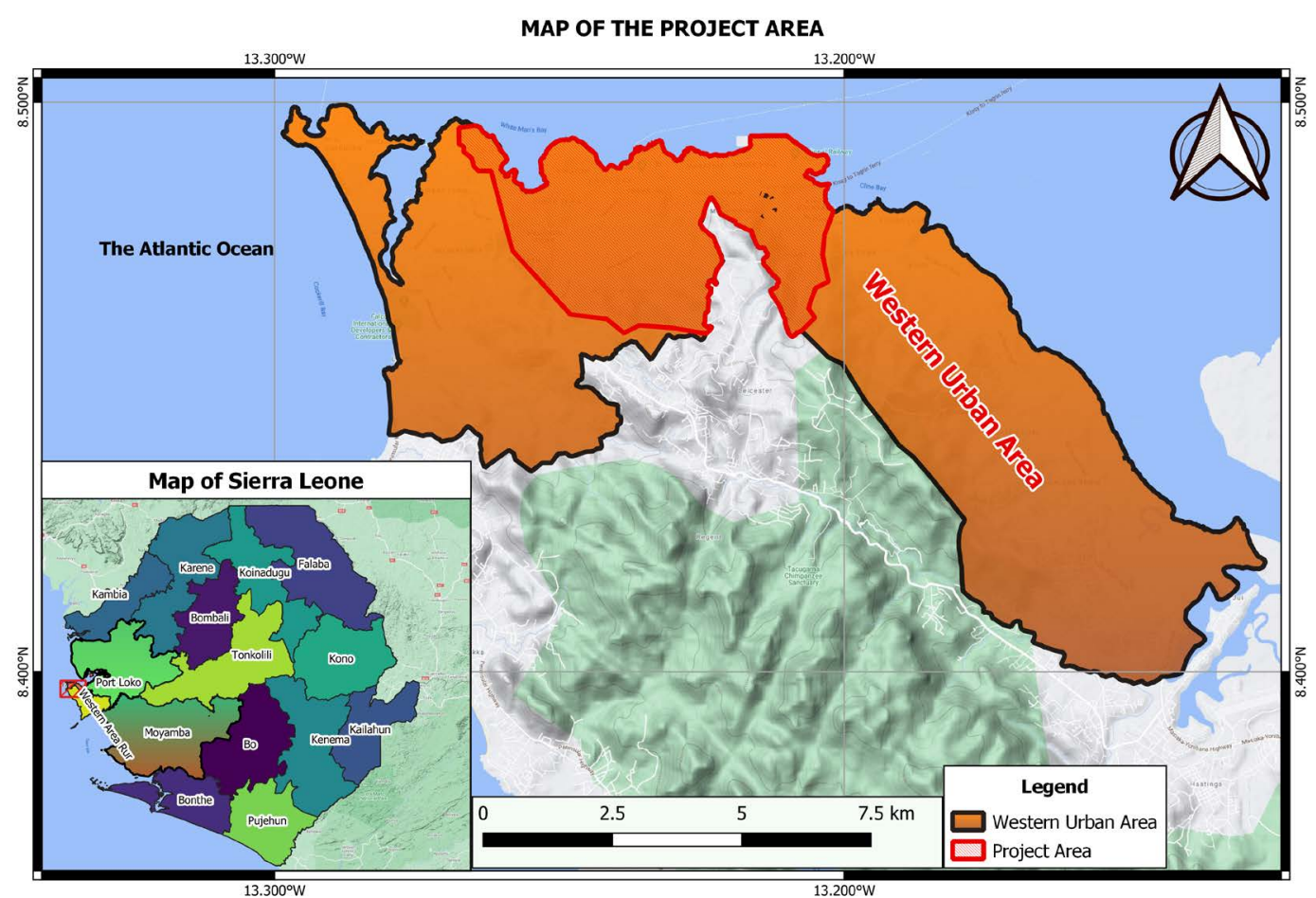

Figure 4. Location of the project area.

wards: East I, East II, East III, Central I, Central II, West I, West II, and West III. The East End regions are the most densely populous of the three regions within Freetown (Government of Sierra Leone, 2015b).

The ten-year brutal war which started in 1991 and ended in 2001 brutally obstructed the economy of Freetown and infrastructural growths. These included, but not limited to; the vandalization of waste management gear such as large skip containers, skip trucks and other related facilities etc. There was also a massive upsurge in the Western Urban population from 563,000 in 1991 to an estimated high of 1.2 million in 2020 (World Bank Open Data|Data, 2020; World 
Statistics Day 2020-Connecting the world with data we can trust|United Nations, 2020). It follows from the world's Population statistical data that the population of Western Urban has average increments of 15,900, 22,300, 30,500 between 1991-2000, 2001-2010 and 2011-2020 respectively (Figure 5).

According to the World Statistics and Demographic data (2020) collected and processed for western urban, there is a consistent pattern of population growth. And it has been projected that the population will increase up to approximately 1.8 million by 2035 (Figure 6).

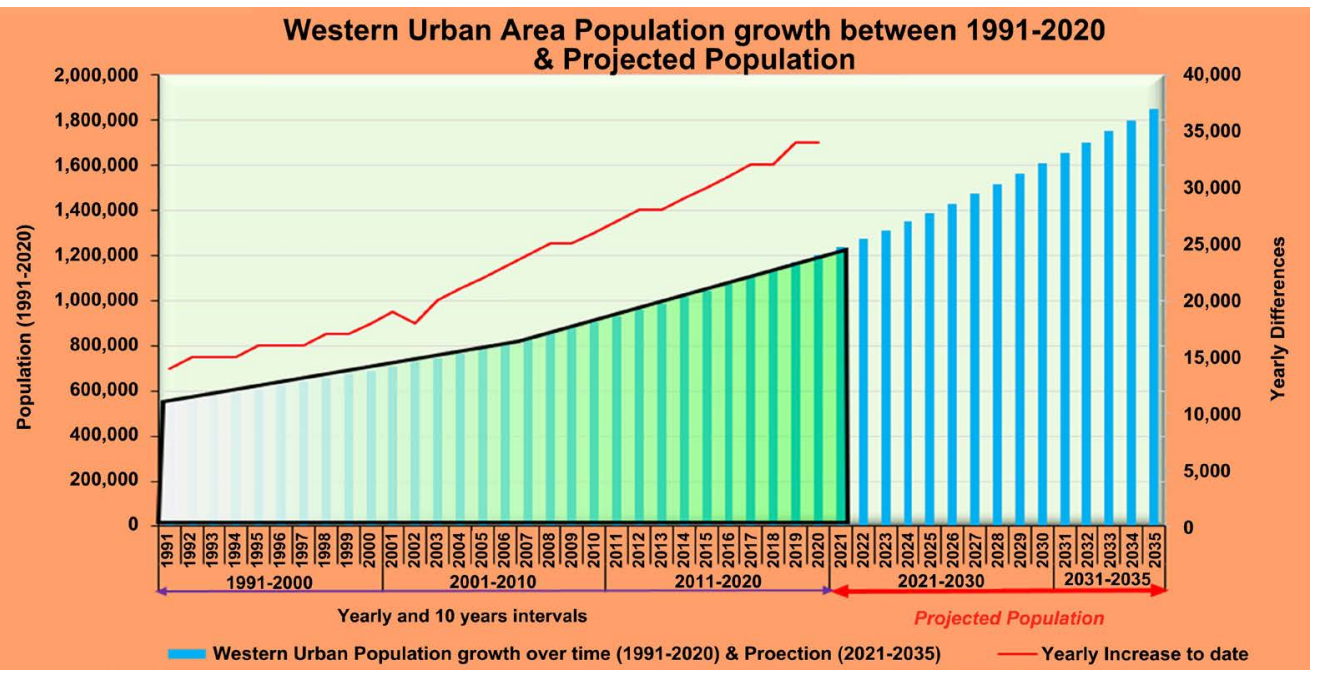

Figure 5. Western urban area population growth between 1991-2020, yearly increase to date, and projected population (2021-2035). Raw data source: (World Population Statistical data 2020). Graph developed by the author of the research project.

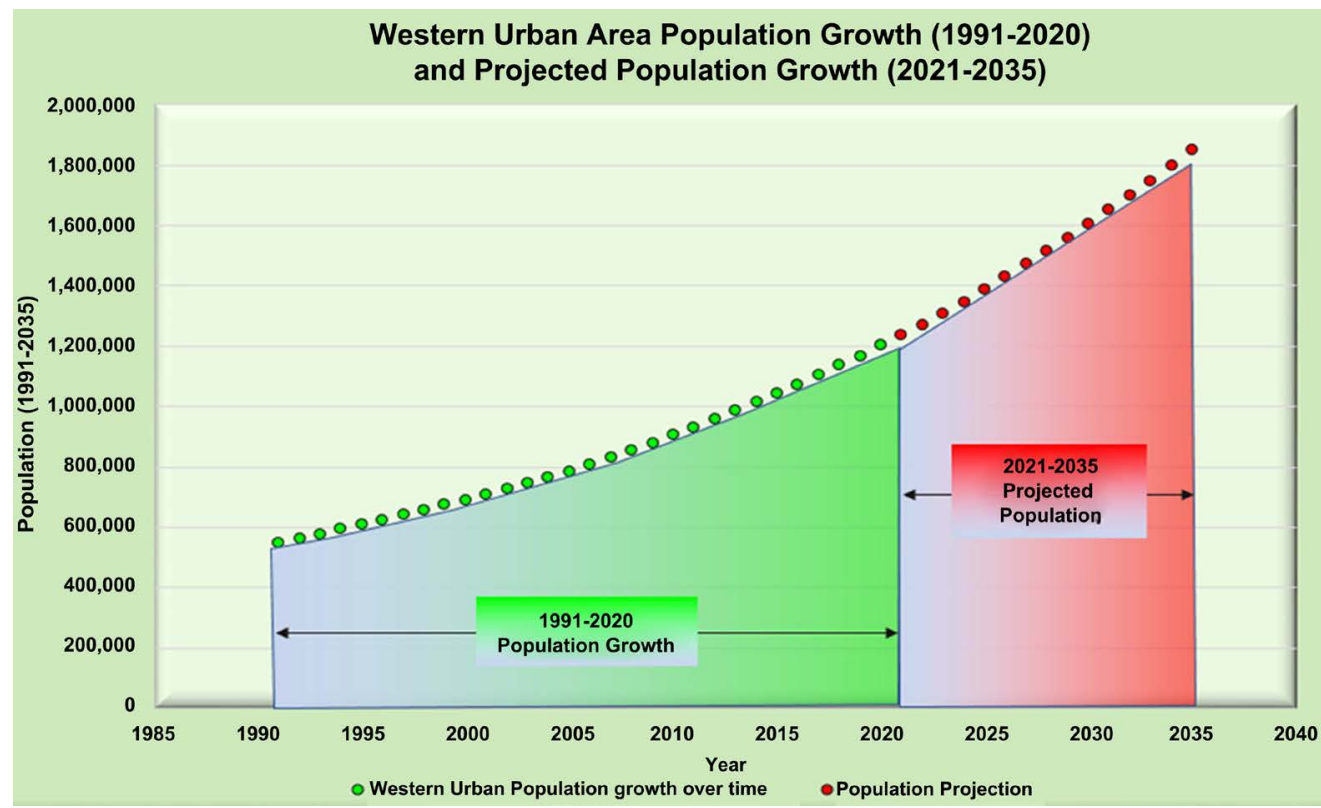

Figure 6. Western urban area population growth between 1991-2020, and projected population growth (2020-2035). Raw data source: (World Population Statistical data 2020). Graph developed by the author of the research project. 


\section{Overview of Solid Waste Management Situation in the Freetown Metropolitan}

Municipality Solid waste management is the most persistent environmental problem confronted by Freetown Western Urban settlement. Sierra Leone population is 7.8 million and that of Freetown Metropolitan area is 1.2 million (World Population Prospects-Population Division-United Nations, 2019). Freetown is the largest producer of solid waste in Sierra Leone (Ahmad et al., 2004). Despite a host of policies and regulations, solid waste management in Freetown is taking alarming magnitudes during the past decade, and by each passing day. It is estimated that over 742 tons/day of garbage is created in the Freetown metropolitan area. Over $84 \%$ of the generated waste is biodegradable organic waste, which are mostly from residential and local vegetable markets. Furthermore, the limited Freetown industry contributes roughly 20 tons/day of wastes. Manufacturing wastes comprise typically broken bottles, primarily from local brewery, waste cans, rags and plastic, minor amounts of hazardous wastes etc. These wastes are frequently unbagged and predisposed by the industry at each of the landfills at relatively no cost (Documents \& Reports-All Documents The World Bank, 2004). From the daily waste generated in Freetown, only $30 \%-35 \%$ is effectively collected and disposed of in approved dumpsites. Irresponsible and indiscriminate disposal of MSW (Sankoh, 2013) has contributed to blockage of drainages and choking, and eventually flooding of streets during heavy rains (Figure 3). Inappropriate and unscientific collection and disposal of MSW triggers environmental upheaval, as the city is presently not well equipped with provisions for the execution of integrated waste management Programmes (IWMP) across the constituencies and wards.

The Freetown Metropolitan Area, despite being a prototypical example for other municipalities in Sierra Leone, managing its generated solid waste has always been a huge task for the current wastes collecting city council. Thus, the absolute necessity to engage and encourage more services of private waste organisations in order to ameliorate the burden of waste collection and disposal. A major vital issue is the late collection of household solid waste across many difficult-to-access areas. Sometimes, the wastes are not picked until after a week or more. Subsequently, the waste containers run-off and litters the backgrounds (Figure 1). Another undesirable practice is to overload collection vehicles with waste to reduce the number of anticipated trips, this has demanded attention by environmental activists and has triggered caution to prevail on pertinent administration to follow contemporary waste transportation guideline and ethics.

\subsection{Waste Characterisation and Categorization}

According to (Oyebode, 2018) at least four main properties characterises solid waste;

1) Toxicity: wastes which are injurious or lethal when ingested or absorb; 
2) Corrosive: are wastes that include acids or bases, and are capable of corroding mental containers;

3) Reactive: are unstable in nature, and they cause explosions, toxic fumes when heated or exposed to high temperatures;

4) Ignitability: a waste that can generate fires under certain condition, e.g. waste oils and certain solvents.

These wastes take various forms, such as; being hazardous, non-hazardous, mixed waste or being radioactive. In general, solid waste are caused by factor not limited to:

1) Urbanization;

2) Population growth;

3) Modernization;

4) Increase in industrials manufacturing.

Broadly speaking, wastes, can be categorized into controlled and non-controlled (Gogra, Yao, Kabba, Sandy, Zaray, Gbanie et al., 2010) and are better described by their sources, the sorts of waste generated, the configuration and production rates. Consequently, in order to design an effective solid waste management system for a growing urban metropolitan, an understanding of these characteristics is necessary. The most pivotal aspect of waste categorising is accuracy of its constituents, as all other waste management requirements strongly centre on categorisation accuracy. In addition, it is as well suitable to determine the weight, volume, density of solid waste generated so as to evaluation the storage necessities and gathering regularities. When these control parameters are in place, an appropriate collection method can be established.

\subsection{Waste Generation and Source in the Freetown Metropolitan}

The generation rate of solid waste is generally stated in kilograms per person per day (kpd) and its density in kilograms per cubic meter. In the Freetown Metropolitan Area, the waste stream is typically a constituent of garbage, which comprises 50 - 85 percent of all the waste (Gogra, Yao, Kabba, Sandy, Zaray, Gbanie et al., 2010).

Biodegradable, Non-biodegradable, non-hazardous and hazardous solid waste etc. constitute waste generated in Freetown. Another source of solid waste in the Freetown Municipality is coming from imported second-handed goods from the developed nations. Old items such as Chairs, mattresses, refrigerators, computers, generators, air conditioners etc., are normally near the end of their life cycles in those nations, and spend little time with their final owners before being discarded as unwasted material. In some exceptional cases, there are certain very cheap, but high-risk electronic appliances people buy with a local trade tag "buy without testing the appliance, and no return or refund of goods once taken out of the shop".

Unfortunately, as at the time of this research, the quantities of wastes generated in Freetown's waste stream remain unknown. However, it is estimated that 
over 742 tons/day of garbage is generated in the Freetown metropolitan area (Sood, 2004). Of this, over $85 \%$ is biodegradable organic waste, mostly from residential and vegetable markets.

\subsection{Distribution of Garbage Containers and Monthly Collection Rates across Freetown Metropolitan Area}

A very limited data exists about the precise number of garbage skips in Freetown due to poor information management, but what is provided below was a study carried out by Sood (2004) (Table 1).

Table 1. Distribution of garbage skips and their average monthly collection rates.

\begin{tabular}{ccccc}
\hline $\begin{array}{c}\text { Zone } \\
\text { Number }\end{array}$ & Zone Range & $\begin{array}{c}\text { Number of } \\
\text { of Skips }\end{array}$ & $\begin{array}{c}\text { Collection } \\
\text { Frequency }\end{array}$ & $\begin{array}{c}\text { Estimated } \\
\text { Population }\end{array}$ \\
\hline 1 & Calaba Town to Ferry Junction & 11 & $30 \%$ & $158,000-200,000$ \\
2 & Ferry Junction to East End Police Station & 9 & $20 \%$ & $185,000-210,000$ \\
3 & East End to St. John & 8 & $25 \%$ & $250,000-285,000$ \\
4 & St. John to Juba Bridge/7-Battallion & 26 & $50 \%$ & $275,000-410,000$ \\
& Total number of operational skips & 54 & $31.2 \%$ & \\
\hline
\end{tabular}

Source: Sood (2004).

\subsection{Solid Waste Collection and Transportation System in the Freetown Metropolitan}

This is a critical functional element, and in most cases, it is an obligatory constituent of municipal solid waste management service. This is because, throughput and efficiency of this service is extremely determined by collection and subsequent transportation. Presently, in Freetown Municipality, there are a number of approaches of solid wastes collection, such as door-to-door solid waste collection by local private agencies, individuals with tricycles, single-persons pick up and a monthly general cleaning waste collection at designated locations.

Collection efficiency is strongly influenced by economic strength of neighbourhoods. Collection in economically better neighbourhoods is performed three to five times on a weekly basis on the average. This is a desirable collection rate of recurrence. Nevertheless, collection in poor or deprived neighbourhoods has less frequently, on the average, once or at most twice a week. The primary reason for the disparity in collection frequency between the better neighbourhoods and the deprived neighbourhoods is roads condition. In economically better neighbourhoods the roads are fairly good, making vehicular movement for waste collection pretty easier. Marketable areas in Freetown are usually serviced at night, as daytime collection is very difficult due to crowded nature of such areas. Although there seems to be relatively regular cleaning at major commercials, piles of garbage can be seen on any day in such agricultural market places. Therefore, provision and timely servicing of sufficient garbage containers could ameliorate such unlawful and indiscriminate dumping of waste. 
Currently, Freetown has no designated central solid waste transfer station and sewage treatment plant. At the household level, 60 - 70 percent of the city's population uses pit latrines, and over $25 \%$ have septic tanks. Inappropriate upkeep and repairing of these systems signify serious health and environmental threats to the general public. The Freetown City Council, Ministry of Health and Sanitation are accountable for emptying cesspits at household and business levels. These administrative arms use slurry trucks and bowzers to drain out and dispose of the effluents. The collected feces are spread in a polder with alternating pits at the Kingtom landfill. Upon drying up, a polder's contents are covered with soil and the product used as fertilizer after a few months. The current slurry pond keeps run out of capacity, and its overflowing sewage is led via a 6-8 feet-connecting pipe to an unlined pit in its locality. This pit is further connected to a source of tidal water.

Generally, waste collection in Freetown is extremely low. Special pickup days are set up for collection of massive items like abandoned furniture, tree cuttings and huge stumps. Due to low collection frequencies, the uncollected wastes are illicitly and indiscriminately dumped in open spaces, storm-drainage channels, water bodies, burnt in open air or deposited along roadsides and streets (combined Figure 2).

\section{Recycling}

In Freetown, there have not been any formal recycling activities, rather more of an informal sector engages on selected valuable materials like aluminium cans, recyclable plastic, scarp metals etc. The Informal recycling sector is somewhat active in waste management system in Freetown. They show up either as itinerant waste buyers looking for scrap metals, retired car batteries and sometime plastic bottles or as scavengers. Their activities have huge influence in the reduction of the net volume of waste discarded of. They have no formal incorporation into the system as a recognised stakeholder in waste management.

\section{Methodology}

In this research, a qualitative approach was used to bring out the findings of the project with respect to wastes management practice in the Freetown Municipality. The phenomenon was scrutinised through observations in numerical illustrations and via statistical investigation. All-inclusive assessments of online materials were exploited in this research and real-world information in the existing state of municipality solid waste management in Freetown was put into perspective in this research project. This research work has to do with solid waste from the biggest urban metropolitan settlement in Sierra Leone. Effective management of solid waste, even if less hazardous when dry, invariably necessitates a more cautious consideration and handling.

The research was designed to carry out a qualitative assessment of solid wastes management in Freetown. The statement, "All-inclusive assessments of online materials involve: peer-reviewed online resources like publications on Freetown 
waste management related-problems, mainly from Google Scholar search engine; WHO and UNEP reports. Key phrases like Freetown solid waste management practices, influence of solid waste on better-quality public health in Freetown, sustainable waste management practice in Freetown, influencing factors that impede solid waste management practice in Freetown, the role of governance in Freetown waste management practice etc. were used to obtain reliable and consistent data and facts for this study. Using the above phrases in Google Scholar search engine, an average of 1950 results and metadata of scholarly literatures were shown.

The results were streamlined and filtered out to get consistent facts about qualitative situational analyses of solid waste management practice in Freetown. That is, how it had, and continues to influence better-quality public health and environmental sustainability. Those scholarly reviewed literatures and other results and reports, mainly from WHO and UNEP were compared with physical observations along major streets and communities that were overtly mentioned in those literatures and reports. Ninety-five percent of the selected reports and peer-reviewed literatures/publications show consistent influencing factors resonating around better-quality public health and environmental sustainability. Using this qualitative research type, the author was able to establish that the problem of SWM for better-quality public health is residents' attitude about waste and institutional deficiencies.

Solid waste management encompasses the undermentioned operational units:

1) Collection from source and storage of solid waste;

2) Transportation of waste;

3) Effective disposal of waste.

\subsection{Integrated Solid Waste Management}

Integrated solid waste management refers to the strategic approach to sustainable management of solid wastes covering all sources and aspects; from generation, segregation, transfer, sorting, treatment, recovery and disposal in an integrated manner, with an emphasis on maximizing resource use efficiency. The U.S. Environmental Protection Agency (EPA) (2018) defines ISWM as a complete waste reduction, collection, composting, recycling, and disposal system. An efficient ISWM system considers how to reduce, reuse, recycle, and manage waste to protect human health and the natural environment. A conceptual framework regarding ISWM is often good for understanding an integrated waste management system. However, it has little or no use in practical application, especially in this qualitative assessment. As such, it is not presented in the research work.

\subsection{Waste Prevention}

This is at the top of waste hierarchy in the waste pyramid. It is also known as source reduction (prevent waste from being generated). Waste prevention in- 
volves approaches that lead to manufacturing products to last much longer, fewer packaging, reusing and/or instead of disposable ones. An effective waste prevention supports a reduced handling, treatment and disposal costs and eventually decrease the generation of contaminants and pollutants evasion to the atmosphere from waste handling and disposal processes. Waste prevention processes are not limited to:

1) Recycling and Composting.

2) Disposal:

a) Land filling and;

b) Combustion.

\section{Discussions of Findings}

The Freetown Municipality is challenged with managing the solid wastes being generated. Given cognizance of the illiteracy rate, coupled with the very feeble consequences for nonconformity to waste management policies and regulations, many residents at large in the metropolitan are mostly unsupportive with apparently diminutive sensitivity to the garbage around their surroundings.

This study reveals that no reliable and consistent estimates of the quantities of wastes, especially hazardous waste produced in Freetown is known. A German study carried out gives an estimate of 7500 tons produced by approximately 30 manufacturing companies yearly. Furthermore, a study done by (Sood, 2004; Gogra, Yao, Kabba, Sandy, Zaray, Gbaniea et al., 2010) estimated that an average of $0.45 \mathrm{~kg}$ person/day of garbage is produced in the Freetown Western Urban Municipality. Biodegradable organic waste accounts for the most (over 84\%) without construction, demolition debris and yard wastes, but counting toxic, medical, and hazardous wastes. They are frequently disposed of with regular wastes in landfills. Due to poor economic growth, past 11 years domestic civil war, and other related factors, it is likely that these quantities may have increased over time.

No segregation or pre-treatment, especially at households' level of wastes do exist, and no current environmental monitoring (either by authorities or voluntarily by environment activists/officers) takes place at households in Freetown. A majority of industrial wastes are disposed of at the landfills by private arrangements with local waste collecting individuals and agencies.

It is sad to know that in the Freetown Municipality, there are deficiencies in industry-specific environmental guidelines, and has an inclusive frail institutional strength, which needs to be reviewed via creating and solidifying institutional framework. Largely, regularity of waste collection in the municipality is very low, and the uncollected waste materials are sometimes indiscriminately buried, burnt, or illicitly dumped in open spaces; along the streets or roadsides, water bodies, drainage channels. The key problems obvious in the system are exceedingly insufficient equipment, quite inconstant levels of service, inefficient or no environmental control systems, and a public with seemingly wee or no 
understanding to the garbage in their surroundings. Moreover, due to equipment shortage, insufficient budgets, lack of internal controls, lack of update-to-date and adequate information and records related to the solid waste management, lack of institutional and regulatory frameworks for obtaining equipment, legislative implementation etc., are some of the major hitches on the operative aspect of the SWMP and service in the municipality. Efficient services will depend on effective administrative and organizational systems, as they are very crucial to a sustainable SWM scheme. Despite the inestimable combined exertions of the new companies (Masada and Co), the government and its partners to clean the city of its loads of waste, there is an absolute necessity for the involvement of potential investors and/or benefactors to upgrade waste management issues. Solid waste management problems in Freetown should be addressed sustainably, for environmental and health improvement of the lives of all Freetown residents. Therefore, in the context of Freetown metropolitan, there is an alarming need of a sound institute, for an all-encompassing and suitable waste management to be boosted.

\section{Conclusion}

It can be established that the main problems with SWM in the Freetown Metropolitan area are: residents' attitudes, insensitivity and perceptions to waste; and institutional deficiency. Although there are tight and/or restricted budgets, incapability to raise enough revenues through user subscriptions, municipal bonds, but as well a poor administrative and organizational set up are also a stern limitation to successfully implement and run the SWMP schemes. As a matter of urgency, the Freetown Western Urban Metropolitan needs to formulate new solid waste management policies, and revive its existing waste management regulatory framework to be more attractive for private sectors to participate through investment in solid waste collection, reprocessing and reusing. Also, the ministry of health should improve its collaborative synergy with the Freetown Municipality to intensify, monitor and enforce sanitation laws as well as regulate the activities of current private waste management agencies on improved and best sustainable practices. Enchanting the support further on solid waste management, municipality authorities and policy makers have to strengthen policies against littering the environment and the indiscriminate disposal of waste. The several heaps of dumps here and there in Freetown pose grave environmental and health problems, and there is an urgent need to put a check on them. There is an absolute necessity to look outside the problems and co-operate on finding workable solutions that are practicable in the Freetown municipalities. The city's SW had been, and continues to be managed by both government and seemingly private sectors, yet the health and environmental issues are becoming insurmountable.

The use of open dumps/landfills remains the most viable option of SW disposal in Freetown, primarily due to its ease of operation. It is the cheapest, sim- 
plest, and utmost cost-effective technique of final discarding waste for inhabitants of Freetown Urban metropolitan. Nevertheless, there is a crucial need to upgrade the open dumping system. It would be essential to upgrade it to a semi-controlled landfill:

1) The waste should be covered with soil on a consistent basis to avoid disease vectors, like flies, from getting into the waste, and develop breeding grounds. This also will lessen the amount of odour that is emitted from the dumpsites;

2) The base of any new dumps should be compacted, to reduce infiltration of leachate to ground water;

3) The dumps should be restricted off in order to stop animals and scavengers from getting access into the dumpsite.

There is poor sensitivity on the health risks and environmental impacts related to poor waste management ethics by a large number of residents in the city; such as dumping of refuse in drains and water channels, on open dump sites, and burning of refuse in open places indiscriminately.

Experience in developing nations shows that a well-organized waste management institution should be self-governing, and has decision-making authority to design, monitor and establish sustainable SWM approaches.

\section{Recommendations}

Based on this qualitative study, this report recommends that the following be taken into consideration:

1) Encourage high investment in infrastructure and reasonable human empowerment for administrative and technical operations;

2) A well-organized corrective approach and/or rehabilitation be carried out as an emergency remedial measures on waste management facilities in the city. This should be backed up with development and implementation of lasting measures on all waste management utilities; or else, it will unpleasantly influence the living environments of residents in the city, thereby compromising their environment and well-being;

3) There should be a vigorous and/or an aggressive enlightenment campaign for waste segregation at source and recycling programmes and funding for scavengers in the city;

4) Sensitization on attitudinal change and perception of individuals and the society towards Solid waste.

Regrettably, a supportable solid waste administrative system is outside the capacity of any metropolitan unaided. This is the case of the Freetown Urban Municipality. In order to fill in this gap, municipality authorities and policy makers in many nations are progressively incorporating private sector and communities as vital members.

Priority is given to segregation of wastes, if possible, at the source of production; into reusable and non-reusable, hazardous and non-hazardous constituents; providing secure methods of waste collection and transportation, and dis- 
posal. It is believed that effective implementation of these recommended measures will aid the creation of a sustainable waste management practice in the municipality in Freetown with a better-public health approach to all residents.

\section{Conflicts of Interest}

The author declares no conflicts of interest regarding the publication of this paper.

\section{References}

Acharya, H. (2018). Municipal Solid Waste Management; Problem and Opportunity.

Ahene, R., Bagdonavicius, A., Barra, A. F., \& Galpin, C. (2019). Support to the Sierra Leone Land Agenda: Policy Note. Washington, DC: World Bank. https://doi.org/10.1596/32022

Ahmad, J. et al. (2004). World Development Report 2004: Making Services Work for Poor People. Washington, DC: The World Bank.

Bernstein, J. (2004). Social Assessment and Public Participation in Municipal Solid Waste Management-Toolkit. The World Bank.

Callegaro, S., Marzoli, A., Bertrand, H., Blichert-Toft, J., Reisberg, L., Cavazzini, G. et al. (2017). Geochemical Constraints Provided by the Freetown Layered Complex (Sierra Leone) on the Origin of High-Ti Tholeiitic CAMP Magmas. Journal of Petrology, 58, 1811-1840. https://doi.org/10.1093/petrology/egx073

Chalokwu, C. I. (2001). Petrology of the Freetown Layered Complex, Sierra Leone: Part II. Magma Evolution and Crystallisation Conditions. Journal of African Earth Sciences, 32, 519-540. https://doi.org/10.1016/S0899-5362(01)90112-5

Ferede, T. (2011). Green Framework in Gondar Town. Addis Ababa, Ethiopia.

Gogra, A. B., Yao, J., Kabba, V. T. S., Sandy, E. H., Zaray, G., Gbaniea, S. P. et al. (2010). A Situational Analysis of Waste Management in Freetown, Sierra Leone. Journal of American Science, 6, 124-135.

Government of Sierra Leone (2015a). Draft National Land Policy of Sierra Leone. p. 129.

Government of Sierra Leone (2015b). Sierra Leone: Western Area Urban District Map. p. 1.

Kaindaneh, P. M. (2015). Sierra Leone: Land Governance Assessment Framework (LGAF). https://doi.org/10.1596/28511

Mishra, A. R., Mishra, S. A., \& Tiwari, A. V. (2014). Solid Waste Management-Case Study. International Journal of Research, 2, 396-399.

Ochiai, T. (2016). The Bifurcated Development of Land Policy in Sierra Leone. Asian Journal of African Studies, 40, 137-172.

Ogwueleka, T. (2009). Municipal Solid Waste Characteristics and Management in Nigeria. Journal of Environmental Health Science \& Engineering, 6, 173-180.

Oyebode, O. J. (2018). Evaluation of Municipal Solid Waste Management for Improved Public Health and Environment in Nigeria. European Journal of Advances in Engineering and Technology, 5, 525-534.

Peel, M. C., Finlayson, B. L., \& McMahon, T. A. (2007). Updated World Map of the Köppen-Geiger Climate Classification. Hydrology and Earth System Sciences, 11, 1633-1644. https://doi.org/10.5194/hess-11-1633-2007

Redshaw, P., Boon, D., Campbell, G., Willis, M., Mattai, J. et al. (2019). The 2017 Regent 
Landslide, Freetown Peninsula, Sierra Leone. Quarterly Journal of Engineering Geology and Hydrogeology, 52, 435-444. https://doi.org/10.1144/qjegh2018-187

Reed, B., \& Mena-Moreno, R. (2016). WASH in Emergencies Problem Exploration Report: Solid Waste Management.

Sankoh, F. P. (2013). Problems of Solid Waste Management in Developing Urban Cities: A Case Study of Freetown, Sierra Leone. American Journal of Environmental Protection, 2, 113-120. https://doi.org/10.11648/j.ajep.20130205.11

Soni, A., Patil, D., \& Argade, K. (2016). Municipal Solid Waste Management. Procedia Environmental Sciences, 35, 119-126. https://doi.org/10.1016/j.proenv.2016.07.057

Sood, D. (2004). Solid Waste Management Study for Freetown, Sierra Leone (Component Design for the World Bank, Draft Report. P078389.

Tchobanoglous, G., \& Kreith, F. (2002). Handbook of Solid Waste Management. New York: McGraw-Hill Education.

The World Bank (2004). Documents \& Reports - All Documents. https://documents.worldbank.org/

United Nations (2020). World Statistics Day 2020-Connecting the World with Data We Can Trust.

https://www.un.org/en/desa/world-statistics-day-2020-connecting-world-data-we-cantrust

Unruh, J. (2008). Land Policy Reform, Customary Rule of Law and the Peace Process in Sierra Leone. African Journal of Legal Studies, 2, 94-117. https://doi.org/10.1163/221097312X13397499736507

US EPA (2018). Criteria for the Definition of Solid Waste and Solid and Hazardous Waste Exclusions. Hazardous Waste.

https://www.epa.gov/hw/criteria-definition-solid-waste-and-solid-and-hazardous-wast e-exclusions

World Bank Open Data/Data (2020). https://data.worldbank.org/

World Population Prospects-Population Division-United Nations (2019).

https://population.un.org/wpp/ 